\title{
Strengthening Local Political Leadership through institutional design: How and Why
}

\author{
Tina Øllgaard Bentzen, Christian Lo and Marte Winsvold
}

\section{Introduction}

In his book Political Order and Political Decay (2014), Francis Fukuyama makes a compelling argument that the stability of institutions can also lead to their downfall. By failing to adapt to changes in the circumstances that brought them to life, the inherent conservatism of political institutions can become a source of political decay. In this perspective, the long-term success of political systems is characterized by institutional innovation and adaptable organizations capable of modifying their internal procedures in response to an ever-changing environment.

As one of democracy's most important cornerstones, local political leadership is perceived as a main target in need of innovation to meet such changing circumstances (Steyvers, Reynaert and Valcke 2012). Over recent decades, academic observers in the European setting have pointed to a wide number of developments urging the need to innovate political institutions at the local level. For example, in many countries the policy portfolio of local political organizations has vastly outgrown the size they were originally designed to manage. Simultaneously, local governments have become increasingly entangled with the multiple levels of government that frame the execution of municipal tasks (Steyvers et al. 2012). These developments put new strains on local political institutions that are also facing new demands from citizens regarding efficient governance, the quality of service delivery, and democratic participation (Torfing et al. 2012). Moreover, years of new public management-inspired labour division between politicians and administration, a proliferation of statutory rights, and economic recession have, according to some observers, left local politicians with dwindling room to manoeuvre and an increasing sense of disempowerment (Torfing and Ansell 2017). Such perceived de-politicization challenges both the input and output legitimacy of local politics. Input legitimacy decreases when democratically elected representatives accountable to their constituencies are no longer in charge of policy development; output legitimacy decreases when policies are not forged on knowledge about local contexts, but rather on national regulations, or are hampered by dire public economies.

This diagnosis has produced a call for stronger and more pronounced political leadership (Elgie 2014; Helms 2012) that has translated into a multitude of organizational reforms aimed 
at strengthening political leadership through institutional design (Grönlund, Bächtiger and Setälä 2014; Newton and Geissel 2012; Reuchamps and Suiter 2016; Smith 2009). Although the precise definition of political leadership is contested, the gist of the concept is that democratically elected politicians should be in the driver's seat of policy development. While some comparative studies have identified a general European tendency towards institutional reforms strengthening the executive level of political leadership (e.g. Denters and Rose 2005b), other observers have argued that such changes to leadership have been less pronounced in the Nordic countries (Goldsmith and Larsen 2004). More recently, some studies have suggested that the Nordic countries are currently witnessing a proliferation of experiments with new participatory forms of interactions between citizens and public authorities at the local level (e.g. Sørensen and Torfing 2018; Nyseth, Ringhold and Agger 2019). There is, however, still scarce knowledge about the range of decentralized institutional innovations recently implemented in the Nordic countries, as well as the motives and contextual factors informing them.

In the present study, we set out to map such locally initiated design reforms aimed at strengthening local political leadership in two Nordic countries - Denmark and Norway through a three stepped mixed-methods research design. In the first part of the study, a combination of expert panels and crowdsourcing strategies was used to identify a variety of cases that could speak to the range of different locally initiated design reforms recently implemented in the two countries. In the second part of the study, we conducted a total of 70 interviews, exploring 86 identified cases of design reforms, in an effort to gain more detailed knowledge about these reforms and the reasons for implementing them. Through an analysis informed by theoretical models of political leadership, we developed a typology that categorizes the identified reforms into four types of strategies aimed at strengthening different forms of political leadership. Finally, to gain a more extensive overview of the distribution of such reforms and possible cross-country variations, we conducted a survey in all municipalities of both Denmark and Norway.

Through this elaborate research design, the main question posed in this article is: What forms of political leadership are promoted through locally initiated, institutional design reforms in Danish and Norwegian municipalities?

Institutional design reforms are here understood as intentional changes to the organization or work practices of the municipal council, implemented by the municipalities themselves to 
affect the enactment of political leadership. Although the enactment of leadership is connected to constitutional framing, and thereby, in the words of Greasley and Stoker, "provide support to the idea that institutional design does make a difference" (2008: 728), intentional design changes to formal institutions do not necessarily equal a change to the enactment of political leadership in the intended way. As vigorously demonstrated by the New Institutionalism, the effects of reforms in formal political organizations cannot be $a$ priori determined through their intentions (Peters 2012). Our categorization of reform types, presented in this article, therefore focuses on the intentions, or strategies, that inform the institutional reforms rather than on the actual effect they have on political leadership.

\section{Political Leadership}

The concept of political leadership is, as pointed out by Masciulli, Molchanov and Knight (2009:4), difficult to define essentially because it depends on institutional, cultural and historical contexts. Still, some functions presumed to characterize political leadership recur in a number of definitions. One such function is that of setting agenda, which involves interpreting the situation at hand and identifying the problems in need of political action (Greasly and Stoker 2008; Kellerman 2015; Leach and Wilson 2002). A second frequently emphasized function of political leadership is that of finding solutions to the problems facing the community (Gissendanner 2004; Leach and Wilson 2002; Kotter and Lawrence 1974; Masciulli et al. 2009; Tucker 1995). Finally, a third function is mobilizing support to enable the implementation of solutions to perceived problems (Svara 1990, 1994; DyhrbergNoerregaard and Kjær 2014; Lawrence 1974). We understand political leadership as the enactment of these three functions.

While defining political leadership as a set of functions may appear somewhat objective, theories and ideas about political leadership will inevitably be normatively charged. The deliberate attempts to design such institutional contexts, for example through the self-initiated design reforms discussed here, do not take place in a normative vacuum where all available reforms are equally likely to be chosen. Rather, design reforms will be informed by prevailing democratic ideals and normative notions about political leadership (Leach and Wilson 2002).

Our own efforts to categorize local self-initiated reforms was initially based on a crude distinction between two such normative yardsticks which we assumed were likely to inform leadership reforms in the Danish and Norwegian contexts. The first is the ideal of representative democracy, depicting sovereign and accountable political leaders (e.g. Haus and Sweeting 2006; Kane, Patapart and Hart 2009). The second is the ideal of participatory 
democracy, depicting political leaders as facilitators for wider processes of public decisionmaking involving actors outside the elected assembly (e.g. Sørensen 2006; Torfing and Ansell 2017). As we discuss further below, our initial attempt to categorize the identified design changes in accordance with these two categories as either relatable to representative or participatory ideas of political leadership soon revealed the need for a more detailed typology to encompass the variety of reforms uncovered. Accordingly, this article demonstrates that reforms can be categorized into four categories aimed at strengthening Executive, Collective, Collaborative, or Distributive political leadership. The two broad ideals, representative and participatory political leadership, will be theoretically delineated below. The finer distinction of four separate types of political leadership reforms is developed in dialogue with the empirical evidence.

\section{Representative political leadership}

Ideas of political leadership based on elitist, representative models of democracy emphasize the importance of the power being contained within the electoral chain (Esaiasson 2011). Citizen involvement is limited to casting the ballot; between elections, agenda-setting and decision-making power rests with the elected representatives (Held 2006). Political leadership performed in such an enclosed and regulated environment ensures that responsible representatives may be held accountable on Election Day (Bovens et al. 2014). Reforms aimed at strengthening representative political leadership should encourage and fortify elected representatives in their endeavours to set agendas and develop appropriate solutions to identified problems. Necessary support to implement policies would come from the administrative staff. Reforms aimed at strengthening political leadership could therefore be about strengthening the hierarchical chain of command and control between the elected council and the administration.

In their ground-breaking comparative work on local executives, Mouritzen and Svara (2002) show how executive power may reside with one political leader, usually the mayor, or be dispersed among several leaders. In Denmark and Norway, where local government has traditionally been characterized by the dispersal and sharing of power within the council and by practices of consultation and coalition building, leadership would typically be performed by collective bodies (Hendriks and Karsten 2014:50).

\section{Participatory political leadership}

As opposed to representative elitist notions of democracy, participatory models require involved citizen participation in policy development between elections (Hendriks and Karsten 
2014; Greasly and Stoker 2008). Citizen involvement is assumed to generate relevant knowledge, identify resources, and spur commitment in the community, resulting in innovative and accurate policies that are supported by the community and, therefore, easy to implement (Smith 2009). Participatory models of democracy promote involvement and learning and are assumed to infuse knowledge and resources into the leadership processes, thereby enhancing efficiency (Chambers 2006:104; Haus and Sweeting 2006). A participatory approach would demand that political leaders collaborate with actors outside the council in setting agenda, pointing out solutions, and mobilizing resources to implement policies decided on. The collaborative view has experienced an upsurge in recent decades, often referring to the growing need for politicians to mobilize resources and support in various groups in order to provide increasingly costly public services (Leach and Wilson 2002; Morrell and Hartley 2006; Sørensen and Torfing 2016).

Collaborative political leadership may be defined as leadership styles where leaders are assumed to increase their power by sharing it (Dyhrberg-Noerregaard and Kjær 2014) and is captured inter alia in Svara's (1990) description of facilitative leadership. Facilitative leadership allows political leaders to "accomplish objectives through enhancing the efforts of others" (1990:87) and "promotes positive interaction and a high level of communication among officials in city government and with the public and [...] also provides guidance in goal setting and policy making" (Svara 2003:157). Democracy inspires shared or distributed leadership since any citizen with a cause or a grievance, can legitimately take up a leadership role and mobilize people to support (Kane, Patapan and t'Hart 2009:2). Tendencies towards dispersion of political power is therefore likely to occur, not only between the political and other domains (Kane et al. 2009:5), but also within the political domain, between self-defined groups of citizens (Bolden, 2011; Gronn, 2002; Pearce and Conger 2003 Pearce, Conger, \& Locke, 2008).

The relation between ideals and institutional reforms?

While the two notions of democratic political leadership can be related to quite different institutional designs aimed at regulating the inherent tension between self-government and leadership, they should not be understood as mutually exclusive. Rather, as demonstrated by Hendriks and Karsten (2014), political leaders operate in hybrid regimes where different models of democracy are combined. Moreover, the relation between institutional (re)form, democratic ideals and political leadership may be more complex than suggested by this crude distinction, as, for example, strengthening sovereign leadership of the mayor can serve as a 
means towards participatory ideals by providing the mayor with an increased mandate to facilitate and broker networked policy processes (Steyvers, Reynaert and Valcke 2012).

As previously indicated, institutional reforms are seldomly explained purely as the results of decoupled shifts in prevailing democratic ideals, but are more often interpreted as responses to shifting contexts presenting political leaders with new dilemmas and challenges (e.g. Fukuyama 2014; Denters and Rose 2005a; Torfing et al. 2012). Based on the latter assumption, we can assume that the patterns in the choice of institutional reforms reflect how local decision-makers experience such imperatives for change and what they perceive as necessary to strengthen local political leadership. Accordingly, with data collected from the interviews in the second part of our study, the stated intentions and justification informing the reforms have been applied to develop the typology presented below. To qualify as a reform addressing political leadership, the reforms should aim at improving the politicians' ability to perform at least one of the three core leadership functions discussed above.

\section{Case selection and presentation of case countries}

Denmark and Norway are ideal "most likely" cases for studying variations of reforms in institutional design aimed at strengthening political leadership (Flyvbjerg 2006). The Nordic countries are generally recognized for high-quality public sectors (Greve, Rykkja and Lægreid 2016). In addition, local governance in both Norway and Denmark is characterized by an extensive political decentralization and along with the other Nordic countries enjoy the highest level of autonomy on almost all variables (Ladner, Keuffer \& Baldersheim 2016). This allows for local experimentation with and variation in choice of institutional designs, which makes Denmark and Norway highly relevant cases for the scope of this study.

Denmark and Norway are relatively similar countries - both unitary states with ambitious welfare states where the municipalities are core welfare providers (Rose and Ståhlberg 2005; Aarsæther and Mikalsen 2015). Municipalities are run by local councils, which are democratically elected every fourth year. The municipal council is the highest municipal body and being elected as a councillor entails responsibility for important public assets and dispositions. The task portfolio of the municipalities in the two countries is quite similar the councils being responsible for providing services within education (pre-school, primary and lower secondary schools), health and social care (primary health services, elderly care, homecare, social welfare, etc.), utilities (water supply, sewerage, waste), local roads, spatial planning, firefighting, public libraries, integration of immigrants, environmental protection, and culture. 
In both Denmark and Norway, local governments are, with some restrictions, allowed to decide the specific design of the political organization in their municipalities. and have considerable discretion regarding institutional design. The local council may, for example, alter the committee structure of the council, the frequency and form of their meetings, the degree of delegation to the administration, the extent of citizens-involvement in policy development processes, and so on.

The relationship between politicians and administrators and the role of the mayor is, however, somewhat differently regulated in the two countries. As de jure leader of the administrative organization, the Danish mayor has more extensive formal powers and responsibilities than the Norwegian mayor (Sletnes 2015). The Norwegian mayor, however, has vast informal powers, partly due to the organization of contact between the political and administrative systems: the so-called 'hourglass model' (Mikalsen and Bjørnå 2015). In practice, this means that the contact between the political and administrative parts of the municipal organization is largely restricted to the mayor and the chief administrator. Political leadership may, in other words, mainly be exercised in the narrow neck between the two bulbs of the hourglass. The ideal of a clear-cut separation of politics and administration has also been dominant in Denmark but has been applied in a more pragmatic manner, resulting in a more collaborative practice between political leaders and administrative staff (Christensen, Christiansen and Ibsen 2011).

Norway is more sparsely populated than Denmark: The 5.3 million Norwegians are spread over an area nine times larger than the 5.8 million Danes enjoy. Although most Norwegians live in urban areas, half of Norway’s 422 municipalities have less than 5,000 inhabitants. On average, a Norwegian municipality has about 12,000 citizens, while the average population of the 98 Danish municipalities is approximately 57,000. This means that the administrative resources in the local municipalities are expectedly less specialized in Norway than in Denmark.

In 2007, a major structural reform was carried out in Denmark, reducing the number of municipalities from 271 to 98. In Denmark, the amalgamation reform has created larger local organizations, and an increased distance between the citizens and their political leaders (Hansen 2015; Nielsen and Vestergård 2010). A similar structural reform was initiated in Norway in 2015, but the result of this reform is still unclear. 
Since the financial crisis, Danish municipalities have been worse off financially than their Norwegian counterparts and have been obliged to reduce public spending. This has encouraged municipalities to look around for new, more efficient ways of providing welfare services, and to mobilize alternative resources (Larsen 2014).

\section{Research design and methods}

As depicted in Figure 1, several research strategies were applied in the mapping of institutional design changes presented in this paper.

\section{[Figure 1 here]}

The first part of our study was an initial mapping with the aim of identifying a larger case collection of municipalities that had recently made changes to the institutional forms or work practices of the municipal council. Rather than generating a representative selection of cases, this part of the study was designed to gain an overview of the diversity of institutional design reforms at play. In both Norway and Denmark, we assembled two separate expert panels who were asked to point to relevant municipalities. In Norway, the first panel consisted of 10 academic experts, while the second included 25 administrative practitioners on the national and regional levels. The latter panel included administrative practitioners from the Norwegian Ministry of Local Government and Modernisation, the Norwegian Association of Local and Regional Authorities, and all 17 County Governors' Offices in Norway. In Denmark, similarly, the first panel counted seven academic experts, while the second consisted of six administrative practitioners including Administrative CEOs, chief consultants and external consultants specialized in municipal development. Furthermore, a crowdsourcing strategy was included in the research design. In Norway, an advertisement was placed in a widely read magazine aimed at municipal organizations named Kommunal Rapport. In Denmark, articles advertising the mapping were published in two magazines aimed at readers within local governments: DenOffentlige.dk and Danske kommuner. In all these publications, readers were explicitly asked to notify the project team about municipalities relevant to the project.

In the second part of the study, structured phone interviews were conducted in all Danish and Norwegian municipalities where design reforms were identified. For the interviews, informants with in-depth knowledge of the identified measures and changes were sought, mainly among the political or administrative leadership. A total of 70 phone interviews were conducted by the authors. The interviews followed a common interview guide with questions exploring the nature of the institutional reforms and the reasons for implementing these 
reforms. Informants were also asked to point out other municipalities implementing institutional design changes, thereby adding an element of snowballing to the mapping. In Norway, the initial mapping and the following interviews identified a total of 27 reforms spread across 20 different municipalities. In Denmark, we identified 59 reforms in 23 municipalities. These reforms met two criteria: First, they were aimed at strengthening one or more of the three core functions of political leadership (agenda setting, solution finding, and resource mobilisation). Second, we only included reforms that were autonomously initiated at the local level. Inter-municipal projects were thus excluded from the mapping. Since many municipalities were found to implement more than one reform, the number of reforms exceeded the number of municipalities.

The initial mapping and interviews assisted us in developing a typology of institutional reforms supporting four different forms of political leadership. However, to validly map the extent and variations in institutional reform, the third part of the study conducted a survey involving all 422 Norwegian and 98 Danish municipalities. The survey was sent to the administrative chief responsible for supporting the local council in the municipality in the fall of 2018. The response rate in Norway was $74 \%$ and in Denmark $86 \%$. The respondents were asked whether the institutional reforms mapped in the first and second part of the study were used in the municipality. All types of institutional reforms were univocally connected to one of the forms of political leadership in the developed typology, enabling us to aggregate subscores to an average for all four categories of political leadership.

In the following, we present a typology of institutional designs strengthening four types of political leadership. The four-fold typology emerged as we sought to fit the empirical evidence of design reforms identified in the first and second part of the study, to our preconceptions of ideal types of political leadership. The typology hence has both a theoretical and an empirical baisis.

\section{A typology of political leadership.}

Based on the initial mapping and interviews, we developed a broad categorization of design reforms. Our deductive point of departure was that political leadership is often theorized in terms of either a representative or a participatory democratic ideal. We therefore started mapping the design reforms in these two groups: reforms aimed at strengthening the internal power of councils, and reforms aimed at strengthening politicians' interaction with citizens or other stakeholders. 
While many reforms fitted neatly into one of the two categories, part of the empirical data continued to resist the two initial categories. First, it became clear that within the category of representative leadership reforms, two rather distinct goals were being pursued: While some institutional reforms were particularly aimed at strengthening the mayor or the council's executive board, others were aimed at the city council as a collective entity. We therefore distinguish between executive and collective political leadership, in line with Mouritzen, \& Svara (2002) and Hendriks \& Karsten (2014).

One group of participatory reforms was distinct in its ambition to promote communication and collaboration between politicians and citizens. These reforms, which we labelled collaborative leadership, aimed to engage citizens by i.e. arranging citizens meetings, debates and collaborative committees to bring citizens' input into the policy process. A second subcategory of participatory reforms, which we eventually identified as a category of distributive leadership, included arrangements that delegated power to sub-municipal entities governed by self-recruited citizens formally accountable neither to the council nor to the local community. This form of political leaderhip is rooted in a procual understandings of leadership, which involves that power and influence is shared or distributed among a plurality of actors regardsless of their formal leadership (Bolden, 2011; Gronn, 2002).

We argue that these four identified reform types can be placed along two axes according to the goal they pursue. The first axis labelled "ideal of power dispersion", refers to how dispersed political power should be. The second axis labelled "democratic ideal", refers to the initial distinction between the representative ideal of retaining the power within the municipal organization and the participatory ideal of sharing power with citizens. In Figure 2, we place the four types of leadership reforms along the two axes.

\section{[Figure 2 here]}

While both executive and collective political leadership supports a representative democratic ideal, reforms for collective political leadership aim at dispersing power among the democratically elected. Equally, collaborative and distributive leadership reforms both build on participatory, democratic ideals, but while reforms for collaborative leadership acknowledge that decisions should be made by the municipality as a unitary and centralized entity, reforms for distributive leadership aim at dispersing political power throughout the municipality to sub-units, not answering to the municipal council as supreme power holder. 
Based on the interviews, in the following we describe the four types of leadership reforms and the stated reasons for introducing them in more detail.

\section{Executive political leadership}

The first group of institutional design reforms focuses on strengthening the position of what can be considered the top political leadership: The mayor, the committee leaders, and the executive board. The executive reforms identified through the reform mapping in Danish and Norwegian municipalities include e.g. delegating extended decision-making powers to either of these positions, the hiring of advisors to support the top political leadership, schemes for coordinating the efforts and plans of the committee leaders, and instigation of regular meetings among the top political leadership.

Interviewees in both Denmark and Norway pointed to the need to boost the executive power of the municipality when explaining these reforms: The top political leadership were bestowed with extra powers to make the political executive power more efficient and to increase the political decision-making capacity. The narrative justifying this need was often one of previous political inertia and inability to make tough but necessary decisions. Moreover, empowering the executive leadership was seen as a way to counter the very strong position of the Chief Administrator.. As a political advisor from a Norwegian town explained: "I help the mayor put politics on the professional assessments of the administration".

\section{Collective political leadership}

The second group of institutional design reforms focuses on strengthening all council representatives' potential to perform political leadership. The collective design reforms cover a broad range of institutional arrangements, including provding tailored training or regularly thematic workshops for elected representatives to enhance their capacity in policy-making; new meeting forms designed to spur political discussion; schemes for information exchange with or learning from the municipal administration (or particular public services); or city council protocols ensuring all councillors have the opportunity to speak.

As with the executive reforms, the collective reforms were also explained with the need to strengthen the politicians' vis a vis the administration. However, whereas the executive reforms were aimed at regaining political decision-making power previously delegated to the administration, the collective reforms were justified with reference to policy development power. There seemed to be a widespread concern that the administration had become too powerful in terms of agendasetting and the actual development of solutions and policies.. Several of the interviewees stressed that the politicians should take a more active part in 
developing policies, and especially that policies "with a clear political character should be prepared by a political committee and not by the chief administrator".

The argument that the administration has grown too powerful was present in both countries, but received much more emphasis in Norwegian municipalities. Most notably, informants talked about "reinstating the politicians as leaders", and "taking the power from the administration and giving it back to the politicians". Informants suggested that the underlying structural factor responsible for the imbalance between politicians and administration was the system in which the chief administrator prepares all political cases and recommends how the council shall vote. Thus, political leadership in the sense of setting agenda and pointing out solutions was perceived as being dominated by the chief administrator in collaboration with the mayor, while paralyzing the rest of the council.

\section{Collaborative political leadership}

Informed by a participatory, democratic ideal, institutional reforms aimed at supporting collaborative political leadership are intended to involve citizens and other relevant municipal actors in processes of policy development. Collaborative reforms establish arenas where politicians and citizens can join forces in defining problems, developing solutions and mobilizing the necessary resources. An example of this type of reform is the formation of collaborative ad hoc committees, in which citizens are invited to join the elected representatives in developing policy in a specific area.

Collaborative design reforms were justified with reference both to the input and to the output side of politics. As for the input side, collaborative models were justified by deontological arguments: Collaboration should take place because it is the right thing to do. Democracy means governing by the people and collaborating with the people will move policy development closer to this ideal. A number of informants also pointed to the democratic principle that people affected by a decision should be able to influence on it.

As for the output side, policies developed in collaboration with citizens were often considered more innovative, as citizens are expected to bring "fresh air" into the council hall in the form of new ideas and new knowledge. Moreover, some of the interviewees assumed that when with citizens, politicians would be released from their party political "reins" and be able to think more freely.

A final and very much referredargument for collaborative arrangements was the necessity of drawing on a wider set of resources than those available within the municipal administration. 
"Because there are not enough resources to deliver the services the citizens need, we must open up the process (of welfare production) to the citizens", an informant in one municipality said. In another municipality an informant explained that "The main aim of the [collaborative committees] was to mobilize existing resources beyond those at the disposal of the municipal organization".

\section{Distributive political leadership}

As with collaborative designs, distributive design reforms are also inspired by the participatory democratic ideal. They deviate from collaborative reforms, however, in that the political power is not shared but rather delegated to groups of non-elected citizens. Thus, these reforms are rooted in distributive or shared leadership ideals in which self-governance becomes the objective (Bolden, 2011; Gronn, 2002). Examples include funding or facilitation of citizen-driven initiatives or projects, and delegation of decision-making power to nonelected groups. These initiatives may be small (e.g., citizens proposing to plant flowers along the road if the municipality provides fees) or they may be larger (e.g., citizens initiating schemes for integrating immigrants into their neighbourhoods).

Such power distribution involves a shift in the democratic ideal towards self-governance rather than co-governance. The distributive reforms could be interpreted as measures not strengthening, but instead weakening, political leadership. However, our informants presented the distributive arrangements as measures to strengthen local political leadership: First, the arrangements were assumed to the council of the burden of making detailed decisions requiring local knowledge, thereby freeing time for strategically important policy-making. Second, as with collaborative leadership reforms, the distributive reforms were assumed to mobilize resources locally. And third, the distributive reforms were also deontologically justified - it was deemed right and legitimate to let those affected decide in matters concerning them.

Cross-national variation and why?

In the initial mapping of design reforms, all the 86 identified cases were assigned to one of the four reform types. In the few cases where a reform supported more than one type of leadership, the primary aim of the reform as defined by the interviewee, was used to decide on the categorization. The sorting of all 86 cases showed that $8 \%$ of the design reforms fell in the category of executive leadership, $27 \%$ in the category of collective leadership, $43 \%$ in the category of collaborative leadership and $22 \%$ in the category of distributive leadership. The results from the initial mapping helped us form a picture of the landscape of leadership 
reforms, but as the cases were selected through a non-random mechanism, the variation of different reforms did not allow us to conclude on the prevalence of each reform type.

Based on the typology of the initial mapping, we developed a survey questionnaire that was sent to the chief administrators of all Danish and Norwegian municipalities. The questions were designed to capture the observed variation in the four different types of reforms: executive, collective, collaborative, and distributive. The operationalizations and frequencies of the four reform types are displayed in Table 1. Table 1 contains two types of information: First, the percentage of municipalities within each country that has implemented different institutional designs are displayed. Second, a score is displayed for each of the four categories of institutional design. The score is computed by adding the proportion of municipalities having implemented the three types of institutional design within each category, divided by three.

[Table 1 here]

Table 1 shows that the institutional reforms aimed at strengthening political leadership are used more extensively in Denmark than in Norway across all four categories. The average number of institutional arrangements for strengthening political leadership varies between 3.6 in Norwegian and 7.6 in Danish municipalities. These results supports the initial impression from the pre-case study. In particular, institutional reforms supporting distributive reforms are widely implemented in Denmark while only very scarcely implemented in Norway.

Moreover, the survey data reveal that municipalities implement design reforms across the four categories, indicating that institutional reforms strengthening different forms of political leadership are used as supplements rather than as substitutions.

While the survey data do not allow us to fully explain the observed variation in reform patterns, the qualitative data from the interviews give some pointers towards explaining how national contexts inform the choice of reform.

\section{Discussion}

The study provides new understanding about how institutional reforms are used to strengthen different forms of political leadership and shows significant differences between Danish and Norwegian municipalities. While the prevalence of all types of reforms is higher in Denmark, the reasons given for choosing a certain design reform are fairly consistent across municipalities and across countries: Reforms strengthening sovereign leaderships are explained by the interviewees as countermoves to too-powerful administrations while reforms 
strengthening participatory leadership are explained as a remedy to a perceived loss of contact between citizens and their elected representatives. In the Danish context, where the latter perception was far more pronounced, this need to reconnect citizens and their elected representatives is, to some extent, explained by the interviewees as a consequence of the increased distance put between the two by the amalgamation reform. Moreover, in Denmark, the extensive implementation of either collaborative or distributive institutional reforms is explained with reference to poor municipal economy. While Norwegian municipalities also justify such reforms in economic terms, this is more often done with reference to a possible future decline. The fact that Denmark was more severely hit by the financial crisis of 2008 than Norway wastherefore appears to be one reason why more Danish municipalities introduce participatory reforms aimed at resource mobilization.

While the justifications for reforms provided in the qualitative data give some partial explanations for the observed differences, there may also be other explanations for the much more extensive use of institutional design reforms in Danish municipalities. For example, it could be argued that the bigger Danish municipalities imply bigger administrative developmental resources. Adopting new ideas of institutional design requires translators that can both de- and re-contextualize concepts into the organizational practice (Røvik 2011). The reform eagerness of Danish municipalities may, thus, also be connected with greater developmental "muscles" associated with competences, norms and resources supporting translation of new ideas.

Whether reforms of political leadership are strategically picked to address underlying structural problems or whether problems are understood in light of existing norms is a question largely left unanswered by our data. Both by defining the borders for acceptable political action and by providing ready-made solutions for policy problems that arise within their domain, political discourse and prevailing ideas of political leadership play key roles in the formative moment of institutional development (Peters 2012). The justifications for reforms mapped in our study may therefore be equally indicative of a common dominant discourse, providing ready-at-hand justifications, as they are of underlying structural problems. The rhetoric of collaboration and co-creation has for some time dominated the public discussion about how to organize local democracy in Denmark (see Torfing and Triantafillou, 2017). As ideological constructs, such concepts can be understood as intertwined with the somewhat exaggerated claims attached to interactive governance, both among policy makers and in academic discourse (for discussion, see Torfing et al., 2012 and 
Davies, 2011). Although attempts have been made by actors at the national level in Norway to adopt the same mind-set - both the Ministry of Local Government and the Norwegian Association of Local and Regional Authorities have launched several initiatives in this regard - the idea, it seems from the interviews made in this study, has not to the same extent resonated with the public or the politicians on the local level. This may be because it addresses a problem not (yet) perceived as important, or because Norwegian political traditions differ from those of the Danish in more significant ways than anticipated. For example, as anthropological observers have noted, the institutions of local government in Norway are highly characterized by their long-lasting traditions for wide political participation and an intertwinement between governmental bodies and civil society on a local level (Barnes, 1954; Park, 1998; Vike, 2018). Accordingly, the call for new reforms promoting collaborative or distributive leadership might, thus, find less resonance among local decision-makers who deem such participatory practices to be already in place.

One important observation from our study is that institutional design reforms supporting different forms of political leadership often co-exist within the same municipalities. The data, however, does not univocally reveal whether this coexistence is harmonious or conflictual. On the one hand it might be argued that power cannot simultaneously be kept and shared or even distributed; on the other, the complexity of political leadership means that the use of only one form of political leadership across all cases and contexts appears too simplistic. For example, some municipalities argue that they need to strengthen the collaboration and horizontal political leadership among the politicians before they can bring citizens into the process of cocreating policy. In this case, strengthening sovereign political leadership is a prerequisite to enhancing collaborative leadership. These examples, while not representative, illustrate the need for further understanding of how, and to what extent, various forms of institutional designs interplay.

\section{Conclusion}

The aim of this article was to explore and map which forms of political leadership are promoted through locally initiated, institutional design reforms in Danish and Norwegian municipalities.

Through a three-stepped process employing a mixed-methods research design, we set out to explore the variation of locally initiated institutional reforms aimed at strengthening political leadership in Norwegian and Danish municipalities. Through an initial mapping aimed at 
identifying the variety of reforms in play, and the qualitative investigation of reforms conducted, we developed a typology of reforms based on the type of political leadership ideal they are aimed at promoting. The conceptual typology presented in this article suggests that the identified institutional reforms can be categorized into two types of representative and two types of participatory reforms that support executive, collective, collaborative and distributive political leadership. By operationalizing the developed typology, we mapped the prevalence of the identified institutional design (re)forms applied in the two countries through a survey to all Norwegian and Danish municipalities.

Our study reveals significant differences between the two countries. The most striking finding is that all types of institutional designs forms are used much more extensively in Denmark than in Norway. Moreover, the study reveals interesting differences regarding the choice of reform types and their justifications. Particularly, reforms supporting distributive political leadership are common in Denmark, while only very scarcely used in Norway. The qualitative interviews in our study reveal that participatory (both collaborative and distributive) reforms are frequently justified as a means towards reducing the distance between politicians and citizens. In the Danish setting, this need is partially connected to the extensive amalgamation reforms in 2007, which has, arguably, increased the distance between citizens and their elected political representatives. Moreover, participatory reforms are also frequently justified in economic terms as a means towards mobilizing resources beyond the disposal of the municipal organization.

While in both countries reforms strengthening sovereign (executive and collective) leadership are frequently emphasized as a means towards strengthening politicians vis-à-vis a toopowerful administration, this tendency in justifying reforms was far more outspoken by the Norwegian informants. Our data does not provide any definitive explanation as to this observation. However, it seems reasonable to speculate that the aforementioned cross-national differences in how the relationship between politics and administration is regulated may provide some explanation to why the power relation between the two seems to be given more attention in the Norwegian than in the Danish setting.

Given the extensive local autonomy with regard to institutional setup, variation in reform design is likely to occur in both Norway and Denmark. And indeed we find great variation in institutional designs in both countries. Whether a similar pattern would be found in countries with low organizationsl autonomy at the local level, is doubtful. Moreover, as our study 
shows, specific circumstances and contexts are likely to affect perceptions of problems and corresponding choices of institutional reforms. However, there is reason to believe that, if not the volume or relative distribution of reform types, then the typology is relevant also to other countries. The ideological ideas on which the design reforms are based, are universal democratic ideas providing answers to problems likely to occur in any democratic setting, addressing the relations between executive and collective power, between administration and politicians and between politicians and citizens.

Our findings highlight the need for more extensive knowledge on how contextual factors inform political innovation on a local level, and thus the institutional pathways of local political institutions. Another, logical next question is also whether, and under what conditions, the reforms work as intended. Future research is encouraged to explore this and other relevant questions in an effort to nuance and elaborate the findings of this article.

\section{Litterature}

Aarsæther, N. and Mikalsen, K. H. (2015). Samfunnsbygging, makt og samspill: lokalpolitisk lederskap i Norden, in Aarsæther, N. and Mikalsen, K. H. Lokalpolitisk Lederskap i Norden. Oslo: Gyldendal.

Barnes, J. A. (1954). "Class and Committees in a Norwegian Island Parish.” Human Relations 7(1): 39-58.

Bolden, R. (2011). Distributed leadership in organizations: A review of theory and research. International Journal of Management Reviews, 13(3), 251-269.

Bovens, M., Godwin, R., \& Schillemans, T. (2014). Oxford Handbook of public accountability., Oxford: Oxford University Press.

Chambers, S. (2006). Mayors and schools. Philadelphia: Temple University Press.

Christensen, J. G., Christiansen, P.M,, \& Ibsen, M. (2011). Politik og forvaltning.. København: Hans Reitzels Forlag.

Davies, J. S. (2011). Challenging Governance Theory. University of Bristol: The Policy Press.

Denters, B. and Rose, L. E. (2005a): Local Governance in the Third Millenium: a Brave New World, in Denters, B. and Rose, L. E.: Comparing Local Governance.Basington: 
Palgrave Macmillan.

Denters, B. and Rose, L. E. (2005b): Towards Local Governance?, in Denters, B. and Rose, L. E.: Comparing Local Governance. Basington: Palgrave Macmillan.

Dyhrberg-Noerregaard, N., \& Kjær, U. (2014). Non-zero-sum Leadership Games: Is Facilitative Leadership a Win-win? International Journal of Public Administration, 37(4), 249-258.

Esaiasson, P. (2011). Electoral losers revisited - How citizens react to defeat at the ballot box. Electoral Studies, 30(1), 102-113.

Elgie, R. (2014). The Institutional Approach to Political Leadership. In John Kane and Haig Patapan (Ed.), Good Democratic Leadership Oxford: Oxford University Press.

Flyvbjerg, B. (2006). Five misunderstandings about case-study research. Qualitative Inquiry, 12(2), 219-245.

Fukuyama, F. (2014). Political order and political decay. Macmillan.

Gissendanner, S. (2004). Mayors, Governance Coalitions, and Strategic Capacity: Drawing Lessons from Germany for Theories of Urban Governance. Urban Affairs Review, 40(1), 44-77.

Goldsmith, M., \& Larsen, H. (2004). Local political leadership: Nordic style. International journal of urban and regional research, 28(1), 121-133.

Greasley, S., \& Stoker, G. (2008). Mayors and urban governance: Developing a facilitative leadership style. Public Administration Review, 78(4), 722-30.

Greve, C., Rykkja, L. H., \& Lægreid, P. (Eds.). (2016). Nordic Administrative Reforms. London: Palgrave Macmillan.

Gronn, P. (2002). Distributed leadership as a unit of analysis. The Leadership Quarterly, 13(4), 423-451.

Grönlund, K., Bächtiger, A., \& Setälä, M. (Eds.). (2014). Deliberative Mini-Publics Involving Citizens in the Democratic Process. Colchester: The ECPR Press.

Hansen, S. (2015). The democratic costs of size: how increasing size affects citizen satisfaction with local government. Political Studies, 63(2), 373-389. 
Haus, M., \& Sweeting, D. (2006). Mayors, Citizens and Local Democracy. In Henry Bäck, H. Heinhelt, \& A. Magnier (Eds.), The European Mayor. VS Verlag für Sozialwissenschaften.

Held, D. (2006). Models of democracy. Stanford, California: Stanford University PRess.

Helms, L. (2012). The Importance of Studying Political Leadership Comparatively. In H. L. (Ed.), Comparative political leadership. Hamphire \& New York: Palgrave Macmillan.

Hendriks, F., \& Karsten, N. (2014). Theory of Democratic Leadership in Action. In R. A. W. Rhodes \& P. 'T Hart (Eds.), The Oxford handbook of political leadership. New York: Oxford University Press.

Kellerman, B. (2015). Hard times, leadership in America. Stanford, California: Stanford Business Books.

Kane, J., Patapan, H., \& Hart, P. t’. (2009). Dispersed democratic leadership. In J. Kane, H. Patapan, \& P. t' Hart (Eds.), Dispersed democratic leadership. Oxford, New York: Oxford University Press.

Kocolowski, M. (2010). Shared leadership: Is it time for a change. Emerging Leadership Journeys, 3(1), 22-32.

Kotter, J. P., \& Lawrence, P. R. (1974). Mayors in action, Five approaches to urban governance. New York: John Wiley.

Ladner, A., Keuffer, N., \& Baldersheim H. (2016). Measuring Local Autonomy in 39 Countries (1990-2014). Regional and Federal Studies, 26(3), 321-357.

Larsen, T. S. (2014). Mellem begejstring og budgetfokus: Offentlige ledere og samarbejdsdreven innovation i en krisetid. In E. Sørensen, J. Torfing, \& P. Aagaard (Eds.), Samarbejdsdreven innovation i den offentlige sektor. København: Djøf / Jurist- og Økonomforbundet.

Leach, S., \& Wilson, D. (2002). Rethinking local political leadership. Public Administration, 80(4), 665-689.

Masciulli, J., M.A. Molchanov and W.A. Knight (2009). Political Leadership in Context. In Masciulli, J., M.A. Molchanov and W.A. Knight: The Ashgate Research Companion to Political Leadership. Ashgate. 
Mikalsen, K. H. And Bjørnå, H. (2015). Den norske ordføreren: Begrenset myndighet, mye makt? In Aarsæther, N. and Mikalsen, K. H. Lokalpolitisk Lederskap i Norden. Oslo: Gyldendal.

Mouritzen, P. E., \& Svara, J. H. (2002). Leadership at the ApexPittsburgh: Pittsburgh University Press.

Morrell, K., \& Hartley, J. (2006). A model of political leadership. Human Relations, 59(4), $483-504$.

Newton, K., \& Geissel, B. (Eds.). (2012). Evaluating Democratic Innovations: Curing the Democratic Malaise? Oxon, New York: Routledge.

Nielsen, T., \& Vestergård, C. (2010). Kommunestørrelse og demokrati-effekten af kommunestørrelse på borgernes eksterne politiske effektivitetsfølelse. Politica, 42(2), $145-162$.

Nyseth, T., Ringholm, T., and Agger, A. (2019). Innovative Forms of Citizen Participation at the Fringe of the Formal Planning System, in Urban Planning, Vol.4(1).

Park, George (1998): The Marke Of Power. Newfoundland: Institute of Social and Economic Research.

Pearce, C. L. and Conger, J. A. (2003). All Those Years Ago: The Historical Underpinnigs of Shared Leadership. In Pearce, C. L. and Conger, J. A (Eds): Shared Leadership. Sage Publications.

Pearce, C. L., Conger, J. A., \& Locke, E. A. (2008). Shared leadership theory. The Leadership Quarterly, 19(5), 622-628.

Peters, B. G. (2012): Institutional Theory in Political Science. New York: Continuum.

Reuchamps, M., \& Suiter, J. (Eds.). (2016). Constitutional Deliberative Democracy in Europe. Colchester: ECPR Press.

Rose, Lawrence E. and Krister Ståhlberg (2005): The Nordic Countries: still the 'promised land', in Denters, B. and Rose, L. E.: Comparing Local Governance. Basington: Palgrave Macmillan.

Røvik, K. A. (2011). From fashion to virus: An alternative theory of organizations' handling of management ideas. Organization Studies, 32(5), 631-653. 
Sletnes, I. (2015). Ordførerrollen i norden i et rettslig perspektiv, in Aarsæther, N. and Mikalsen, K. H. Lokalpolitisk Lederskap i Norden. Oslo: Gyldendal.

Smith, G. (2009). Democratic Innovations: Designing Institutions for Citizen Participation. Cambridge: Cambridge University Press.

Steyvers, K., Reynaert, H., and Valcke, T. (2012): 'Army of One or Join the Club'? In Helms, L. (ed.) Comparative Political Leadership.. Basingstoke: Palgrave Macmillan.

Sørensen, E. (2006). Metagovernance - the changing role of politicians in processes of democratic governance. The American Review of Public Administration, 36(1), 98-114.

Sørensen, E., \& Torfing, J. (2016). Political Leadership in the age of interactive Governance. In J. Edelenbos \& I. van Meerkerk (Eds.), Critical Reflections on Interactive Governance. Northampton, Cheltenham: Edward Elgar Publishing limited.

Sørensen, E., \& Torfing, J. (2018). Co-initiation of collaborative innovation in urban spaces, in Urban Affairs Review, 54(2), 388-418.

Svara, J. H. (1990). Official leadership in the city, patterns of conflict and cooperation. New York: Oxford University Press.

Svara, J. H. (2003). Effective mayoral leadership in council-manager cities: Reassessing the facilitative model. National Civic Review, 92(2), 157-172.

Torfing, J., \& Ansell, C. (2017). Strengthening political leadership and policy innovation through the expansion of collaborative forms of governance. Public Management Review, 19(1), 37-54.

Torfing, J., Peters, G. B., and Sørensen, E. (2012): Interactive Governance. Oxford: Oxford University Press.

Torfing, J., \& Triantafillou, P. (2017). (red.), New Public Governance på dansk.København: Akademisk Forlag.

Tucker, R. C. (1995). Politics as leadership (2nd ed.). University of Missouri Press, Columbia, Missouri.

Vike, Halvard. 2018. "The Protestant Ethic and the spirit of Political Resistance". In Bendixen, S., M. B. Bringslid and H. Vike Egalitarianism in Scandinavia, 111-133. Cham, Switzerland: Palgrave MacMillan. 